\title{
Role of Aortic Input Impedance in the Decreased \\ Cardiovascular Response to Exercise with Aging in Dogs
}

\author{
Frank C. P. Yin, Myron L. Weisfeldt, and William R. Milnor, Division of \\ Cardiology, Department of Medicine, and Department of Physiology, The \\ Johns Hopkins Medical Institutions, Baltimore, Maryland 21205
}

A B S T RACT The diminished cardiac output response to exercise with advancing age may be attributable to intrinsic inability of the old ventricle to respond appropriately and/or to an additional loading imposed upon the ventricle by the aged vascular system. The steady (resistance) and pulsatile (characteristic impedance) load components together comprise the vascular load faced by the ejecting ventricle. To study the effect of exercise on both vascular components of load, the aortic input impedance was measured in chronically instrumented young and old beagle dogs during graded treadmill exercise before and after beta blockade. Ascending aortic flow was measured by a cuff electromagnetic flow probe, and pressure was measured by a high-fidelity semiconductor transducer. At low levels of exercise the old animals demonstrated a striking $20 \%$ increase in characteristic impedance and a $28 \%$ decrease in peripheral resistance with no increase in stroke volume. This vascular loading and limitation in stroke volume persisted across the higher exercise levels. In contrast, the young group demonstrated no increase in characteristic impedance, a progressive decrease in peripheral resistance, and a progressive increase in stroke volume across the same exercise levels. These age differences in vascular response and ventricular output were abolished by beta blockade. The groups did not demonstrate a difference in heart rate response, but the young had a greater increase in external left ventricular power than the old across exercise. These data demonstrated a profound difference in the response of young and old vasculature to exercise. At low and intermediate exercise levels the pulsatile vascular load appeared to be a major factor in the limitation of stroke volume in old dogs. At high

Portions of this work were presented at the American Federation of Clinical Research National Meeting, May 1980, Washington, D. C.

Dr. Yin holds a Frank T. McClure fellowship from the Applied Physics Laboratory of the John Hopkins University.

Received for publication 24 October 1980 and in revised form 23 February 1981. levels of exercise, the limited exercise response in the old dog may be caused in part by a diminished inotropic responsiveness as well as by the vascular loading.

\section{INTRODUCTION}

A diminution in exercise response with advancing age is a striking and frequently documented finding. Maximal exercise capacity, oxgyen consumption, cardiac output, and heart rate all decrease monotonically with age in man (1-5) by mechanisms that have not yet been identified. Because exercise is a complex response involving the interaction of many organs, age-associated changes could originate in any of several different systems. The involvement of ventilatory, muscular, and psychological mechanisms, for example, has not been thoroughly investigated, but the central role of the cardiovascular system during exercise makes age-associated alterations in the function of this system of particular interest. Since sympathetic nervous system function assumes a dominant role at high levels of exercise (6), the ageassociated decrease in inotropic and chronotropic response of the heart may play a crucial role in limiting the response to exercise as suggested by some observations on isolated heart tissue and intact hearts (7-9). In addition, factors extrinsic to the heart, such as the peripheral vasculature, could also play a significant role in limiting exercise response with age.

The pumping ability of the heart is coupled to and highly dependent on the state of the vasculature (1013). Aortic input impedance is one method of measuring the vascular load faced by the ejecting left ventricle $(12,14)$, and this load depends in a complex fashion on the size and mechanical properties of the aorta and systemic vasculature $(15,16)$. These determinants of impedance have been shown to change in a complex fashion with age (17-19). For example, there is an increase in size and decrease in distensibility of the aorta with age. These changes affect aortic 
impedance in opposite directions, and thus could counteract each other producing no net change in resting values of impedance. During exercise this balance could be significantly altered as a result of age-associated changes in arterial vasodilatory response to catecholamines (20). Despite these age changes in factors that may affect aortic input impedance, the effect of aging per se on impedance has not been studied in detail. Although there are suggestions of an age-associated increase in input impedance at rest in man $(21,22)$, these data may be confounded by the presence of atherosclerosis. The effect of exercise on aortic impedance similarly has not been clearly delineated, although an increase in impedance during exercise in man has been found $(23,24)$.

The purpose of this study was to determine whether there is an age-associated increase in aortic impedance at rest and during exercise, and to assess the relationship of any age-associated alteration in impedance to other aspects of the cardiovascular response to exercise. To this end, young and senescent dogs were exercised at graded speeds on a treadmill while phasic aortic pressures and flows were recorded. The animals had been prepared by chronic implantation of pressure and flow transducers and measurements were made before and after beta adrenergic blockade to examine the extent to which the vascular response to exercise in young and old is mediated by the beta adrenergic system.

\section{METHODS}

Seven mature (1-3 yr) and seven senescent (10-12 yr) purebred, female beagles obtained from a breeding farm were used for this study. The dogs had no prior history of cardiovascular abnormalities and were free of apparent clinical cardiovascular disease at the time of study. Each dog was trained to run on a specially built, enclosed treadmill before study. The animals were familiarized with treadmill exercise at varying speeds by several exercise sessions a week over a period of 3-6 wk. Each run at a given speed lasted 2-3 min and was followed by a long rest period. No attempt was made to condition the dogs physically, only to acquaint them with the treadmill. Their preparation was considered complete when the dog willingly jumped onto the treadmill and ran at moderate speeds without hesitation.

A left thoracotomy was performed, the ascending aorta was exposed under pentobarbital anesthesia (30 mg/kg i.v.), and a Biotronex electromagnetic cuff flow probe (Biotronex Lab., Silver Spring, Md.) that fit loosely around the ascending aorta was positioned just above the coronary ostia. A miniature Konigsberg semiconductor pressure transducer (Konigsberg Instruments, Inc., Pasadena, Calif.) was placed via an aortotomy in the aortic arch at the junction of the left subclavian artery. A polyethylene indwelling right atrial catheter was also placed for later drug infusion. The chest was then closed, and the animals were allowed to recover for at least 1 wk before any data were obtained. The exercise protocol consisted of having each dog run for $2 \mathrm{~min}$ at zero incline at successive treadmill speeds of $1.7,4.3,7.3$, and $11.7 \mathrm{~km} / \mathrm{h}$ (which will be referred to hereafter as mild, moderate, severe, and extreme levels of exercise, respectively). Between runs the dogs were allowed to recover until the heart rate, blood pressure, and respiratory rate had returned to preexercise levels and remained nearly constant for 5-10 min. Before and during each level of exercise the aortic pressure and flow were recorded on analog tape for subsequent analysis. On a separate day the dogs were returned to the laboratory, at which time an intravenous isoproterenol infusion of 0.64 $\mu \mathrm{g} / \mathrm{kg}$ per min was given while the heart rate response was monitored. The dogs were then given propranolol $(0.15 \mathrm{mg} /$ kg i.v., Ayerst Laboratories, New York) over 2 min. The completeness of the beta adrenergic blockade was tested by repeating the isoproterenol infusion. The identical exercise protocol was then repeated during beta blockade.

The flow probes used were calibrated by infusing saline through an excised length of aorta around which the probe was placed. The pressure transducers were calibrated at $37^{\circ} \mathrm{C}$ in vitro with a mercury column both before surgery and immediately after removal from the dog. Since only minimal base-line drift occurred (1-3 $\mathrm{mm} \mathrm{Hg} / \mathrm{mo})$ and these studies were completed within $1 \mathrm{mo}$, the poststudy atmospheric pressure was assumed to have been the zero pressure level throughout the course of the recordings in vivo. From earlier measurements in our laboratory (25), the flow transducers and flow meter amplifier system had an amplitude response that was flat to $20 \mathrm{~Hz}$ and down $10 \%$ at $50 \mathrm{~Hz}$. The phase lag was almost linear with frequency at a rate of $1.3^{\circ}$ $\mathrm{Hz}$, and the damping ratio was 0.75 . The frequency response of the Konigsberg pressure transducer was flat to at least $1,000 \mathrm{~Hz}$. Appropriate corrections for the frequency response of the flowmeter were applied to the data.

All analog signals were recorded on FM tape and subsequently digitized at 4-ms intervals and calculations were made on a PDP-11/10 (Digital Equipment Corp., Maynard, Mass.) computer as reported (21). At least three nonconsecutive beats for each base-line and exercise level were analyzed and averaged. Zero flow was assumed to be the value of flow in mid-to-late diastole. Standard hemodynamic parameters consisting of aortic pressure and flow, heart rate, stroke volume, cardiac output, and maximum aortic acceleration were recorded and/or calculated directly. Acceleration was obtained by digital differentiation of the flow signal using a five-point least squares algorithm. The flow was first converted to velocity by dividing by the estimated aortic cross-sectional area obtained by subtracting the wall cross-sectional area measured at the time of killing from the inner cross-sectional area of the flow probe. To calculate the aortic input impedance for each beat, the pressure and flow signals were resolved into Fourier harmonics. Only those harmonics whose moduli had values greater than the noise level of the system ( $1 \mathrm{~mm} \mathrm{Hg}$ for pressure and $10 \%$ of mean flow) were used for subsequent calculations. For each harmonic the impedance modulus was calculated as the ratio of the pressure harmonic to the flow harmonic. The corrected flow phase was subtracted from the pressure phase at each harmonic to yield the impedance phage angle. The characteristic impedance $\left(Z_{0}\right)$ was derived by averaging only the significant impedance moduli of frequencies $>5 \mathrm{~Hz}$. External left ventricular hydraulic power was obtained from the pressure and flow harmonics by reported methods (26). The power is expressed as the sum of a steady term and a pulsatile term consisting of the sum of a series of oscillatory terms.

The efficiency with which the external power of the left ventricle was converted into useful work was assessed by calculating the percentage of total power that was pulsatile. The lower the pulsatile power, the more efficient is the transfer of energy from the heart to the vasculature (26-28). Prior studies $(27,28)$ have shown that the contribution of both the 
steady and oscillatory kinetic terms to total power is small. In addition, data in six dogs (three old and three young) revealed that inclusion of the kinetic terms in the power calculations resulted in a $0.7 \pm 0.1$ and $1.2 \pm 0.3 \%$ increase in the percentage of pulsatile power at rest and during exercise, respectively, and did not alter the efficiency calculation obtained from using only the potential power terms. Thus, for this study the contribution of the kinetic power terms has been neglected.

Two independent measures of the reflection characteristics of the aorta and vasculature were examined: $(a)$ the first zero crossing of the impedance angle was estimated by linear interpolation, $(b)$ a reflection index was derived by dividing the maximum minus the minimum value of impedance by the characteristic impedance for frequencies $>5 \mathrm{~Hz}$ : ( $\mathrm{Zmax}$ $\left.-Z_{\min }\right) / Z_{0}$. This latter index estimates the fraction of the traveling wave that is reflected to the proximal aorta from peripheral sites.

Preliminary calculations indicated that there could be a variation of up to $10 \%$ in some variables (characteristic impedance, stroke volume, and the power terms) between peak inspiration and peak expiration either at rest or during exercise. These variations were usually $<5 \%$ in aortic pressure, flow, cardiac output, and resistance. Therefore, the beats selected for analysis were those near the middle of the respiratory cycle, and three such nonconsecutive beats were selected as representative of the resting or exercise conditions.

The data for the resting condition consist of the average of three nonconsecutive beats recorded during stable hemodynamic periods before each of the three lower exercise levels. The variables for these nine beats were tested for statistically significant age differences by using an unpaired $t$ test (29). During the last $15 \mathrm{~s}$ at each exercise level, the average values for three nonconsecutive beats were compared with the average values for three nonconsecutive beats recorded in the resting state immediately preceding the exercise. The exercise data are expressed as changes from the resting values. The effects of age, exercise, and beta blockade were analyzed by repeated measures analysis of variance (30). When interactions between effects were present, the interacting effects were analyzed separately to allow delineation of the influence of the individual underlying effects. All data are presented as mean \pm SEM.

\section{RESULTS}

There was no difference between the young and senescent dogs in total body weight $(10.4 \pm 0.6$ vs. $11.1 \pm 0.6 \mathrm{~kg})$, left ventricular wet weight $(49.5 \pm 2.8 \mathrm{vs}$. $44.9 \pm 3.1 \mathrm{~g}$ ), or body size as assessed either by spine length from atlas to tip of coccyx $(44.6 \pm 1.2 \mathrm{vs.} 47.5 \pm 1.0$ $\mathrm{cm})$ or tibial length $(12.3 \pm 0.3$ vs. $12.6 \pm 0.3 \mathrm{~cm})$. Thus the two groups were closely matched physically and differed significantly only by age $(2.4 \pm 0.3$ vs. 10.5 \pm 1.1 yr, $P<0.01$ )

Before beta blockade. Cardiac output and other standard hemodynamic parameters in the two age groups under resting conditions are presented in the upper half of Table I and the derived aortic impedance parameters are presented in Table II. None of these values differed significantly between the two groups.

Before beta blockade all of the dogs were able to run for $2 \mathrm{~min}$ at the first three levels of exercise. All but one of the young and none of the senescent dogs were able to complete the period of extreme exercise. In these abbreviated runs, cardiovascular collapse as manifested by asystole or profound bradycardia together with severe hypotension necessitated stopping the treadmill before the full 2-min period was completed. All the animals recovered spontaneously within a few seconds of stopping the treadmill without any evidence of untoward effects. These findings indicated a limitation in exercise capacity with advancing age. Since the data for the extreme exercise level are incomplete, only the data for the three lower levels of exercise could be compared statistically.

The exercise data are tabulated in the upper portions of Tables III and IV in which each entry represents the change from the control value immediately before that level of exercise. The results of the overall analysis

TABLE I

Hemodynamics at Rest in Young and Senescent Beagle Dogs*

\begin{tabular}{|c|c|c|c|c|c|c|c|c|c|}
\hline & \multirow[b]{2}{*}{ Age } & \multirow[b]{2}{*}{$n$} & \multirow{2}{*}{$\begin{array}{c}\text { Heart } \\
\text { rate }\end{array}$} & \multicolumn{3}{|c|}{ Aortic pressure } & \multirow{2}{*}{$\begin{array}{l}\text { Cardiac } \\
\text { output }\end{array}$} & \multirow{2}{*}{$\begin{array}{c}\text { Stroke } \\
\text { volume }\end{array}$} & \multirow{2}{*}{$\begin{array}{c}\text { Maximum } \\
\text { aortic } \\
\text { acceleration }\end{array}$} \\
\hline & & & & Systolic & Diastolic & Mean & & & \\
\hline & yr & & bpm & & $m m \mathbf{H g}$ & & liter/min & $m l$ & $\mathrm{~cm} / \mathrm{s}^{2}$ \\
\hline \multirow[t]{2}{*}{ Before beta blockade } & $\begin{array}{r}2.4 \\
\pm 0.3\end{array}$ & 7 & $\begin{array}{r}126.9 \\
\pm 9.8\end{array}$ & $\begin{array}{r}107.4 \\
\pm 5.9\end{array}$ & $\begin{array}{r}65.0 \\
\pm 4.4\end{array}$ & $\begin{array}{r}98.1 \\
\pm 6.5\end{array}$ & $\begin{array}{r}1.51 \\
\pm 0.13\end{array}$ & $\begin{array}{r}12.22 \\
\pm 1.46\end{array}$ & $\begin{array}{l}4,498 \\
\pm 764\end{array}$ \\
\hline & $\begin{array}{c}10.5 \ddagger \\
\pm 1.1\end{array}$ & 7 & $\begin{array}{r}135.0 \\
\pm 8.5\end{array}$ & $\begin{array}{r}127.1 \\
\pm 11.1\end{array}$ & $\begin{array}{l}81.1 \\
\pm 8.1\end{array}$ & $\begin{array}{r}106.4 \\
\pm 9.3\end{array}$ & $\begin{array}{r}1.26 \\
\pm 0.10\end{array}$ & $\begin{array}{r}9.44 \\
\pm 1.26\end{array}$ & $\begin{array}{l}3,975 \\
\pm 780\end{array}$ \\
\hline \multirow[t]{2}{*}{ After beta blockade } & $\begin{array}{r}2.4 \\
\pm 0.3\end{array}$ & 7 & $\begin{array}{r}119.0 \\
\pm 5.7\end{array}$ & $\begin{array}{r}106.6 \\
\pm 5.1\end{array}$ & $\begin{array}{r}71.3 \\
\pm 3.1\end{array}$ & $\begin{array}{r}95.4 \\
\pm 5.9\end{array}$ & $\begin{array}{r}1.46 \\
\pm 0.13\end{array}$ & $\begin{array}{r}12.50 \\
\pm 0.14\end{array}$ & $\begin{array}{l}3,793 \\
\pm 585\end{array}$ \\
\hline & $\begin{array}{r}10.5 \\
\pm 1.1\end{array}$ & 6 & $\begin{array}{r}121.3 \\
\pm 5.7\end{array}$ & $\begin{array}{c}147.8 \ddagger \\
\pm 10.6\end{array}$ & $\begin{array}{l}96.5 \ddagger \\
\pm 7.6\end{array}$ & $\begin{array}{r}112.5 \\
\pm 7.1\end{array}$ & $\begin{array}{r}1.17 \\
\pm 0.13\end{array}$ & $\begin{array}{r}9.91 \\
\pm 1.36\end{array}$ & $\begin{array}{l}3,629 \\
\pm 839\end{array}$ \\
\hline
\end{tabular}

* The values listed represent the average data for the resting periods preceding each exercise level. During each resting period, three nonconsecutive beats were averaged.

$\neq P<0.01$. 
TABLE II

Aortic Impedance Parameters at Rest in Young and Senescent Beagle Dogs*

\begin{tabular}{|c|c|c|c|c|c|c|c|c|}
\hline & Age & $n$ & $\begin{array}{l}\text { Peripheral } \\
\text { resistance }\end{array}$ & $\begin{array}{c}\text { Characteristic } \\
\text { impedance }\end{array}$ & $\begin{array}{l}\text { First zero crossing } \\
\text { of phase }\end{array}$ & $\begin{array}{c}\text { LV total } \\
\text { external power }\end{array}$ & $\begin{array}{l}\text { Oscillatory } \\
\text { power }\end{array}$ & $\begin{array}{l}\text { Reflectance } \\
\text { index }\end{array}$ \\
\hline & $y r$ & & $d y n-s-\mathrm{cm}^{-5}$ & dyn-s-cm ${ }^{-5}$ & $\mathrm{~Hz}$ & $m W$ & percent & \\
\hline \multirow[t]{2}{*}{ Before beta blockade } & $\begin{array}{r}2.4 \\
\pm 0.3\end{array}$ & 7 & $\begin{array}{l}5,678 \\
\pm 655\end{array}$ & $\begin{array}{r}318.6 \\
\pm 30.6\end{array}$ & $\begin{array}{r}6.3 \\
\pm 0.5\end{array}$ & $\begin{array}{r}435 \\
\pm 47\end{array}$ & $\begin{array}{r}23.6 \\
\pm 2.3\end{array}$ & $\begin{array}{r}0.51 \\
\pm 0.08\end{array}$ \\
\hline & $\begin{array}{r}10.5 \\
\pm 1.1\end{array}$ & 7 & $\begin{array}{r}7,056 \\
\pm 1,117\end{array}$ & $\begin{array}{r}417.4 \\
\pm 47.5\end{array}$ & $\begin{array}{r}6.6 \\
\pm 0.5\end{array}$ & $\begin{array}{r}363 \\
\pm 38\end{array}$ & $\begin{array}{r}26.6 \\
\pm 1.6\end{array}$ & $\begin{array}{r}0.32 \\
\pm 0.06\end{array}$ \\
\hline \multirow[t]{2}{*}{ After beta blockade } & $\begin{array}{r}2.4 \\
\pm 0.3\end{array}$ & 7 & $\begin{array}{l}5,644 \\
\pm 687\end{array}$ & $\begin{array}{l}279.4 \\
\pm 29.0\end{array}$ & $\begin{array}{r}6.6 \\
\pm 0.7\end{array}$ & $\begin{array}{l}381 \\
\pm 41\end{array}$ & $\begin{array}{r}18.9 \\
\pm 2.4\end{array}$ & $\begin{array}{r}0.54 \\
\pm 0.05\end{array}$ \\
\hline & $\begin{array}{r}10.5 \\
\pm 1.1\end{array}$ & 6 & $\begin{array}{r}8,141 \\
\pm 1,889\end{array}$ & $\begin{array}{r}362.5 \\
\pm 64.5\end{array}$ & $\begin{array}{r}6.1 \\
\pm 0.2\end{array}$ & $\begin{array}{r}340 \\
\pm 35\end{array}$ & $\begin{array}{r}22.7 \\
\pm 2.1\end{array}$ & $\begin{array}{r}0.51 \\
\pm 0.07\end{array}$ \\
\hline
\end{tabular}

* The values listed represent the average data for the resting periods preceding each exercise level. During each resting period, three nonconsecutive beats were averaged.

of variance across the first three exercise levels are shown in Table $\mathrm{V}$ in which only the $P$ values for those parameters that had a significant variance ratio are listed. To interpret the results, Table III and IV must be considered together with Table V. For example, the change in heart rate demonstrated no interaction among age, exercise, or beta blockade. Thus, the significant variance ratios for the exercise and beta blockade effects indicated that there was a significant increment in heart rate across exercise levels; this increment was significantly decreased after beta blockade, and there was no difference between the age groups in this response.

For other parameters, such as stroke volume, peripheral resistance, characteristic impedance, and power, the interpretation is slightly more complex because there are significant interactions between age and exercise values and/or between beta blockade and exercise values. These interactions necessitated performing separate analyses of variance to test for the significance of the individual effects. For clarity, when separate analysis of variance was necessary, the results of the statistical analyses within an age group are summarized in the legends to Figs. 1-4, and the analysis between age groups is summarized in the legend of the figure. The stroke volume response to exercise is depicted in Fig. 1 in which the mean value of the change at each exercise level is indicated for each group. The symbol refers to the significance of the variance ratio between age groups across all three exercise levels. The young animals had a stepwise increment with each exercise level, whereas the old group demonstrated no increase in stroke volume as demands were increased at successively higher levels of exercise. This limitation of stroke volume in the old group limited the cardiac output that could be achieved to $\sim 65 \%$ of that of the young dogs at the severe exercise level.
Examination of Tables III and V demonstrates that the young group had a slightly larger increment in mean aortic pressure with exercise than the old group. There was no age difference however, in the increment in either systolic or diastolic blood pressures. Thus, the central aortic pressure provided no clue as to the mechanism of the limitation of stroke volume.

The response of systemic vascular resistance to exercise is summarized in Fig. 2. The old group had a large decrement in resistance at the low level of exercise with no further significant changes as the exercise level increased. In contrast, the young group displayed a progressive decrease in resistance with increasing exercise until the decrease in resistance exceeded that of the old group at the severe level of exercise. This age difference in response across exercise was of border-line significance $(P=0.05)$. At the lower exercise levels the old animals actually had more vasodilatation than the young group. Thus, inability to achieve peripheral arterial vasodilatation in the old group was not a factor that limited stroke volume at the lower exercise levels.

The effect of exercise on aortic characteristic impedance is summarized in Fig. 3. The old group displayed a large increment in this parameter beginning with the lowest level of exercise which did not change with further exercise. The response of the young group, however, was significantly different, demonstrating no change from resting levels with exercise. Since characteristic impedance represents a portion of the vascular load imposed on the ejecting ventricle, a constant increase in this parameter with exercise in the old group represents an extra load imposed on the ventricle of the old animal that was not present in the young at the same levels of exercise. This extra load could contribute to the limitation of stroke volume seen in Fig. 1.

Finally, the effect of exercise on left ventricular external power is shown in Fig. 4. In both groups there 
TABLE III

Hemodynamics during Exercise in Young and Senescent Beagle Dogs*

\begin{tabular}{|c|c|c|c|c|c|c|c|c|c|c|}
\hline & \multirow[b]{2}{*}{ Age } & \multirow[b]{2}{*}{$n$} & \multirow[b]{2}{*}{$\begin{array}{c}\text { Exercise } \\
\text { level }\end{array}$} & \multirow[b]{2}{*}{$\begin{array}{l}\Delta \text { Heart } \\
\text { rate }\end{array}$} & \multicolumn{3}{|c|}{$\Delta$ Aortic pressure } & \multirow[b]{2}{*}{$\begin{array}{c}\Delta \text { Cardiac } \\
\text { output }\end{array}$} & \multirow[b]{2}{*}{$\begin{array}{l}\Delta \text { Stroke } \\
\text { volume }\end{array}$} & \multirow{2}{*}{$\begin{array}{l}\Delta \text { Maximum } \\
\quad \text { aortic } \\
\text { acceleration }\end{array}$} \\
\hline & & & & & Systolic & Diastolic & Mean & & & \\
\hline & $y r$ & & & bpm & & $m m \mathrm{Hg}$ & & liters/min & $m l$ & $\mathrm{~cm} / \mathrm{s}^{2}$ \\
\hline \multirow[t]{7}{*}{ Before beta blockade } & $\begin{array}{r}2.4 \\
\pm 0.3\end{array}$ & 7 & Mild & $\begin{array}{r}43.9 \\
\pm 10.0\end{array}$ & $\begin{array}{r}27.7 \\
\pm 8.2\end{array}$ & $\begin{array}{r}19.4 \\
\pm 8.7\end{array}$ & $\begin{array}{r}26.2 \\
\pm 3.2\end{array}$ & $\begin{array}{r}0.79 \\
\pm 0.15\end{array}$ & $\begin{array}{r}1.37 \\
\pm 0.80\end{array}$ & $\begin{array}{l}1,150 \\
\pm 282\end{array}$ \\
\hline & & 7 & Moderate & $\begin{array}{r}61.1 \\
\pm 7.7\end{array}$ & $\begin{array}{r}27.6 \\
\pm 5.7\end{array}$ & $\begin{array}{r}15.6 \\
\pm 4.3\end{array}$ & $\begin{array}{r}21.9 \\
\pm 3.9\end{array}$ & $\begin{array}{r}1.31 \\
\pm 0.23\end{array}$ & $\begin{array}{r}2.71 \\
\pm 1.26\end{array}$ & $\begin{array}{l}1,765 \\
\pm 372\end{array}$ \\
\hline & & 7 & Severe & $\begin{array}{r}75.1 \\
\pm 8.9\end{array}$ & $\begin{array}{r}41.7 \\
\pm 10.6\end{array}$ & $\begin{array}{r}24.0 \\
\pm 7.7\end{array}$ & $\begin{array}{r}31.5 \\
\pm 7.4\end{array}$ & $\begin{array}{r}1.92 \\
\pm 0.20\end{array}$ & $\begin{array}{r}4.98 \\
\pm 0.76\end{array}$ & $\begin{array}{l}2,116 \\
\pm 514\end{array}$ \\
\hline & & 7 & Extreme & $\begin{array}{r}91.1 \\
\pm 15.0\end{array}$ & $\begin{array}{r}40.7 \\
\pm 5.9\end{array}$ & $\begin{array}{r}18.7 \\
\pm 9.2\end{array}$ & $\begin{array}{r}28.7 \\
\pm 6.2\end{array}$ & $\begin{array}{r}2.23 \\
\pm 0.50\end{array}$ & $\begin{array}{r}5.45 \\
\pm 0.72\end{array}$ & $\begin{array}{l}2,982 \\
\pm 797\end{array}$ \\
\hline & $\begin{array}{r}10.5 \\
\pm 1.1\end{array}$ & 7 & Mild & $\begin{array}{r}39.5 \\
\pm 12.1\end{array}$ & $\begin{array}{r}12.7 \\
\pm 5.6\end{array}$ & $\begin{array}{r}7.9 \\
\pm 3.4\end{array}$ & $\begin{array}{r}9.3 \\
\pm 4.7\end{array}$ & $\begin{array}{r}0.54 \\
\pm 0.12\end{array}$ & $\begin{array}{r}1.02 \\
\pm 0.37\end{array}$ & $\begin{array}{l}1,206 \\
\pm 306\end{array}$ \\
\hline & & 7 & Moderate & $\begin{array}{r}55.1 \\
\pm 11.6\end{array}$ & $\begin{array}{r}14.7 \\
\pm 3.8\end{array}$ & $\begin{array}{r}7.7 \\
\pm 2.3\end{array}$ & $\begin{array}{r}11.6 \\
\pm 2.4\end{array}$ & $\begin{array}{r}0.77 \\
\pm 0.12\end{array}$ & $\begin{array}{r}1.37 \\
\pm 0.47\end{array}$ & $\begin{array}{l}1,402 \\
\pm 213\end{array}$ \\
\hline & & 7 & Severe & $\begin{array}{r}69.6 \\
\pm 14.4\end{array}$ & $\begin{array}{r}35.9 \\
\pm 6.4\end{array}$ & $\begin{array}{r}22.0 \\
\pm 3.2\end{array}$ & $\begin{array}{r}24.4 \\
\pm 2.9\end{array}$ & $\begin{array}{r}0.94 \\
\pm 0.19\end{array}$ & $\begin{array}{r}1.31 \\
\pm 0.39\end{array}$ & $\begin{array}{l}1,365 \\
\pm 496\end{array}$ \\
\hline \multirow[t]{7}{*}{ After beta blockade } & $\begin{array}{r}2.4 \\
\pm 0.3\end{array}$ & 7 & Mild & $\begin{array}{r}25.5 \\
\pm 3.9\end{array}$ & $\begin{array}{r}15.7 \\
\pm 7.1\end{array}$ & $\begin{array}{r}8.9 \\
\pm 4.4\end{array}$ & $\begin{array}{r}8.9 \\
\pm 5.7\end{array}$ & $\begin{array}{r}0.36 \\
\pm 0.10\end{array}$ & $\begin{array}{r}0.23 \\
\pm 0.60\end{array}$ & $\begin{array}{r}198 \\
\pm 91\end{array}$ \\
\hline & & 7 & Moderate & $\begin{array}{r}39.0 \\
\pm 3.9\end{array}$ & $\begin{array}{r}15.1 \\
\pm 6.5\end{array}$ & $\begin{array}{r}6.4 \\
\pm 3.2\end{array}$ & $\begin{array}{r}9.3 \\
\pm 5.7\end{array}$ & $\begin{array}{r}0.77 \\
\pm 0.20\end{array}$ & $\begin{array}{r}1.26 \\
\pm 0.82\end{array}$ & $\begin{array}{r}590 \\
\pm 233\end{array}$ \\
\hline & & 7 & Severe & $\begin{array}{r}63.3 \\
\pm 7.6\end{array}$ & $\begin{array}{r}24.0 \\
\pm 6.3\end{array}$ & $\begin{array}{r}13.1 \\
\pm 5.6\end{array}$ & $\begin{array}{r}14.9 \\
\pm 6.8\end{array}$ & $\begin{array}{r}1.15 \\
\pm 0.18\end{array}$ & $\begin{array}{r}1.95 \\
\pm 0.67\end{array}$ & $\begin{array}{l}1,080 \\
\pm 214\end{array}$ \\
\hline & & 6 & Extreme & $\begin{array}{r}74.2 \\
\pm 16.4\end{array}$ & $\begin{array}{r}33.0 \\
\pm 8.0\end{array}$ & $\begin{array}{r}15.2 \\
\pm 5.7\end{array}$ & $\begin{array}{r}29.2 \\
\pm 8.3\end{array}$ & $\begin{array}{r}1.61 \\
\pm 0.39\end{array}$ & $\begin{array}{r}2.92 \\
\pm 0.76\end{array}$ & $\begin{array}{l}1,566 \\
\pm 520\end{array}$ \\
\hline & $\begin{array}{r}10.5 \\
\pm 0.3\end{array}$ & 6 & Mild & $\begin{array}{r}19.3 \\
\pm 5.2\end{array}$ & $\begin{array}{l}-0.2 \\
\pm 4.0\end{array}$ & $\begin{array}{l} \pm 0.3 \\
\pm 2.9\end{array}$ & $\begin{array}{r}2.5 \\
\pm 4.3\end{array}$ & $\begin{array}{r}0.29 \\
\pm 0.04\end{array}$ & $\begin{array}{r}0.76 \\
\pm 0.28\end{array}$ & $\begin{array}{r}183 \\
\pm 141\end{array}$ \\
\hline & & 6 & Moderate & $\begin{array}{r}42.2 \\
\pm 7.2\end{array}$ & $\begin{array}{r}21.5 \\
\pm 7.3\end{array}$ & $\begin{array}{r}11.7 \\
\pm 4.8\end{array}$ & $\begin{array}{r}10.4 \\
\pm 3.6\end{array}$ & $\begin{array}{r}0.53 \\
\pm 0.08\end{array}$ & $\begin{array}{r}0.85 \\
\pm 0.58\end{array}$ & $\begin{array}{r}131 \\
+151\end{array}$ \\
\hline & & 6 & Severe & $\begin{array}{r}52.5 \\
\pm 6.7\end{array}$ & $\begin{array}{r}19.8 \\
\pm 1.7\end{array}$ & $\begin{array}{r}3.2 \\
\pm 3.9\end{array}$ & $\begin{array}{r}14.1 \\
\pm 2.9\end{array}$ & $\begin{array}{r}0.55 \\
\pm 0.10\end{array}$ & $\begin{array}{r}0.22 \\
\pm 0.41\end{array}$ & $\begin{array}{r}145 \\
\pm 215\end{array}$ \\
\hline
\end{tabular}

* All values indicated are changes from the control values immediately preceding that particular exercise level. The averaged resting values during the three lower exercise levels are listed in Tables I and II. Statistical analysis results are summarized in Table $\mathrm{V}$ and Figs. 1-4.

was a stepwise increase with exercise, but the increase was greater in the young than the old group.

After beta blockade. After propranolol infusion, the heart rate increase to the challenge infusion of isoproterenol averaged $20 \pm 6 \%$ of the response to the same dose before beta adrenergic blockade and was not significantly different between the two age groups. The resting hemodynamic and impedance parameters listed in the lower portions of Tables I and II demonstrated that beta blockade increased both the systolic and diastolic aortic pressures in the old dogs so that after beta blockade these values were higher than in the young dogs. Beta blockade did not produce any other significant age differences in resting parameters.

The response to exercise is detailed in the lower portions of Tables III and IV, the analysis of variance is summarized in Table $\mathrm{V}$, and the lower portions of Figs. 1-4 summarize the response of selected variables. Specifically, the heart rate response to exercise was decreased after beta blockade in both groups, but there was still no age difference in the incremental response. The stroke volume response was markedly 
TABLE IV

Aortic Impedance Parameters during Exercise in Young and Senescent Beagle Dogs*

\begin{tabular}{|c|c|c|c|c|c|c|c|c|c|}
\hline & Age & $n$ & $\begin{array}{c}\text { Exercise } \\
\text { level }\end{array}$ & $\begin{array}{l}\Delta \text { Peripheral } \\
\text { resistance }\end{array}$ & $\begin{array}{c}\Delta \text { Characteristic } \\
\text { impedance }\end{array}$ & $\begin{array}{c}\Delta \text { First zero } \\
\text { crossing of } \\
\text { phase }\end{array}$ & $\begin{array}{l}\text { Left ventricular } \\
\text { total external } \\
\text { power }\end{array}$ & $\begin{array}{c}\Delta \\
\text { Oscillatory } \\
\text { power }\end{array}$ & $\begin{array}{c}\Delta \\
\text { Reflectance } \\
\text { index }\end{array}$ \\
\hline & $y r$ & & & dyn s/cms & $d y n-s-\mathrm{cm}^{-s}$ & $\mathrm{~Hz}$ & $m W$ & $\%$ & \\
\hline \multirow[t]{4}{*}{ Before beta blockade } & $\begin{array}{r}2.4 \\
\pm 0.3\end{array}$ & 7 & Mild & $\begin{array}{l}-729 \\
\pm 312\end{array}$ & $\begin{array}{r}17.3 \\
\pm 25.6\end{array}$ & $\begin{array}{r}1.2 \\
\pm 0.7\end{array}$ & $\begin{array}{r}381 \\
\pm 71\end{array}$ & $\begin{array}{l}-0.5 \\
\pm 2.1\end{array}$ & $\begin{array}{l}-0.22 \\
\pm 0.11\end{array}$ \\
\hline & & 7 & Severe & $\begin{array}{r}-2,440 \\
\pm 358\end{array}$ & $\begin{array}{l}-22.7 \\
\pm 34.1\end{array}$ & $\begin{array}{r}0.9 \\
\pm 0.9\end{array}$ & $\begin{array}{r}895 \\
\pm 93\end{array}$ & $\begin{array}{r}4.1 \\
\pm 2.0\end{array}$ & $\begin{array}{l}-0.15 \\
\pm 0.10\end{array}$ \\
\hline & & 7 & Extreme & $\begin{array}{r}-2,736 \\
\pm 607\end{array}$ & $\begin{array}{r}20.9 \\
\pm 26.1\end{array}$ & $\begin{array}{r}2.9 \\
\pm 1.0\end{array}$ & $\begin{array}{l}1,140 \\
\pm 199\end{array}$ & $\begin{array}{r}5.5 \\
\pm 1.6\end{array}$ & $\begin{array}{l}-0.05 \\
\pm 0.06\end{array}$ \\
\hline & & 7 & Severe & $\begin{array}{r}-1,700 \\
\pm 628\end{array}$ & $\begin{array}{r}91.4 \\
\pm 27.7\end{array}$ & $\begin{array}{r}0.7 \\
\pm 0.3\end{array}$ & $\begin{array}{r}453 \\
\pm 67\end{array}$ & $\begin{array}{r}1.3 \\
\pm 0.2\end{array}$ & $\begin{array}{r}0.11 \\
\pm 0.11\end{array}$ \\
\hline \multirow[t]{4}{*}{ After beta blockade } & $\begin{array}{r}2.4 \\
\pm 0.3\end{array}$ & 7 & Mild & $\begin{array}{l}-949 \\
\pm 510\end{array}$ & $\begin{array}{r}43.5 \\
\pm 15.8\end{array}$ & $\begin{array}{r}0.7 \\
\pm 1.0\end{array}$ & $\begin{array}{r}161 \\
\pm 50\end{array}$ & $\begin{array}{r}1.0 \\
\pm 1.7\end{array}$ & $\begin{array}{l}-0.01 \\
\pm 0.10\end{array}$ \\
\hline & & 7 & Moderate & $\begin{array}{r}-1,654 \\
\pm 493\end{array}$ & $\begin{array}{r}103.7 \\
\pm 44.9\end{array}$ & $\begin{array}{r}1.1 \\
\pm 0.7\end{array}$ & $\begin{array}{r}282 \\
\pm 67\end{array}$ & $\begin{array}{r}2.9 \\
\pm 1.5\end{array}$ & $\begin{array}{r}0.04 \\
\pm 0.16\end{array}$ \\
\hline & & 7 & Severe & $\begin{array}{r}-2,128 \\
\pm 562\end{array}$ & $\begin{array}{r}88.9 \\
\pm 16.5\end{array}$ & $\begin{array}{r}1.7 \\
\pm 0.7\end{array}$ & $\begin{array}{r}442 \\
\pm 61\end{array}$ & $\begin{array}{r}6.0 \\
\pm 3.0\end{array}$ & $\begin{array}{r}0.02 \\
\pm 0.18\end{array}$ \\
\hline & & 6 & Severe & $\begin{array}{r}-1,925 \\
\pm 802\end{array}$ & $\begin{array}{r}78.9 \\
\pm 23.4\end{array}$ & $\begin{array}{r}1.2 \\
\pm 0.9\end{array}$ & $\begin{array}{r}259 \\
\pm 37\end{array}$ & $\begin{array}{r}2.0 \\
\pm 0.5\end{array}$ & $\begin{array}{r}0.10 \\
\pm 0.10\end{array}$ \\
\hline
\end{tabular}

* All values indicated are changes from the control values immediately preceding that particular exercise level. The averaged resting values during the three lower exercise levels are listed in Tables I and II. Statistical analysis results are summarized in Table V and Figs. 1-4.

blunted in the young dogs so that the significant age difference which existed across exercise levels before beta blockade was abolished. Similarly, the age differences in the changes of mean aortic pressure, characteristic impedance, total left ventricular power, and vascular resistance were abolished by beta blockade. On the other hand, after beta blockade the young group demonstrated a significantly larger incremental response in maximum acceleration than the old group. There were no age differences in the response of percentage of pulsatile power or reflectance index either before or after beta blockade.

\section{DISCUSSION}

The major finding of this study was that there was a profound difference in the vascular response to exercise in young compared with senescent dogs. In both groups peripheral vasodilation occurred with exercise. The old animals had a large decrease in resistance at the first level of exercise that did not change with increasing exercise, whereas the young animals demonstrated a progressive fall in resistance with increasing exercise. Most importantly, in the old group there was a load imposed by the arterial vasculature on the left ventricle 
TABLE V

Overall Analysis of Variance Results for Hemodynamic and Impedance Parameters*

\begin{tabular}{|c|c|c|c|c|c|c|c|c|c|c|}
\hline Source & HRt & $\mathbf{Q}$ & Sv & $P$ & $\mathbf{R}$ & $\mathrm{Z}_{0}$ & $\mathbf{w}_{\mathrm{t}}$ & $w_{0}$ & $\Delta \mathbf{Z} / \mathbf{Z}_{0}$ & $V_{\max }$ \\
\hline Between ages (A) & & 0.05 & & 0.04 & & & 0.03 & & & \\
\hline Across exercise (E) & $<0.001$ & $<0.001$ & 0.009 & 0.03 & 0.03 & & $<0.001$ & $<0.001$ & & \\
\hline During beta blockade (B) & $<0.001$ & $<0.001$ & 0.003 & 0.02 & & & $<0.001$ & 0.001 & & \\
\hline $\mathbf{B} \times \mathbf{A}$ & & & & & & 0.02 & 0.04 & & 0.04 & \\
\hline $\mathbf{E} \times \mathbf{A}$ & & 0.01 & 0.005 & & 0.07 & & 0.002 & $<0.001$ & & \\
\hline $\mathbf{B} \times \mathbf{E}$ & & 0.01 & 0.05 & & & & 0.002 & & & \\
\hline
\end{tabular}

$\mathrm{B} \times \mathrm{E} \times \mathbf{A}$

* The values listed are only those $P$ values that are significant at close to the $P=0.05$ level for the variance ratios of the hemodynamic and impedance parameters. The main effects tested are between age groups, across exercise levels, and during beta blockade. If any significant interaction appeared between two or more main effects, separate analysis of variance was performed to delineate the contribution of each individual effect to the interaction. The results of these separate analyses for parameters that demonstrate age differences are presented in the legends in Figs. 1-4.

$\$$ Abbreviations used in this table: E, exercise; B, during beta blockade; A, age; HR, heart rate; Q, mean aortic flow; SV, stroke volume; $P$, mean aortic pressure; $R$, peripheral resistance; $Z_{0}$, characteristic impedance; $W_{t}$, total left ventricular external power; $\mathrm{W}_{0}$, oscillatory power; $\Delta \mathrm{Z} / \mathrm{Z}_{0}$, reflectance index; $\mathrm{V}_{\max }$, maximum acceleration.

consisting of a $20 \%$ increase in characteristic impedance that began with the lowest exercise level and persisted throughout higher exercise levels. There was no such loading of the ventricle in the young dogs at equivalent exercise levels. The old dogs were unable to increase stroke volume as the demands on the heart were increased at successively higher levels of exercise. During severe exertion, the cardiac output in the old dogs was consequently only $65 \%$ of that in the young dogs.

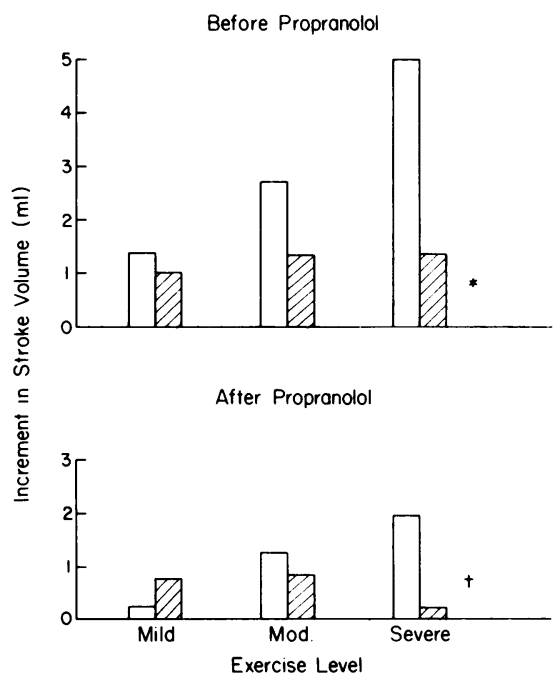

Figure 1 Effect of graded exercise on left ventricular stroke volume represented as mean change from the resting values immediately preceding each exercise level. The symbols refer to the $P$ values for the variance ratio between age groups across the exercise levels. The progressive increases in the young group were significant before $(P=0.005)$ and after $(P=0.006)$ propranolol. The old group demonstrated an inability to increase stroke volume at all three exercise levels. $\square$, young; $\square$, old. $* P=0.02 ; \nmid P=$ NS. Drug $\times$ Age, $P=$ NS.
The load faced by the ejecting ventricle consists of a steady component represented by the peripheral resistance, and a pulsatile component, represented by the characteristic impedance (12-14). In isolated heart studies, an increase in either load component tends to

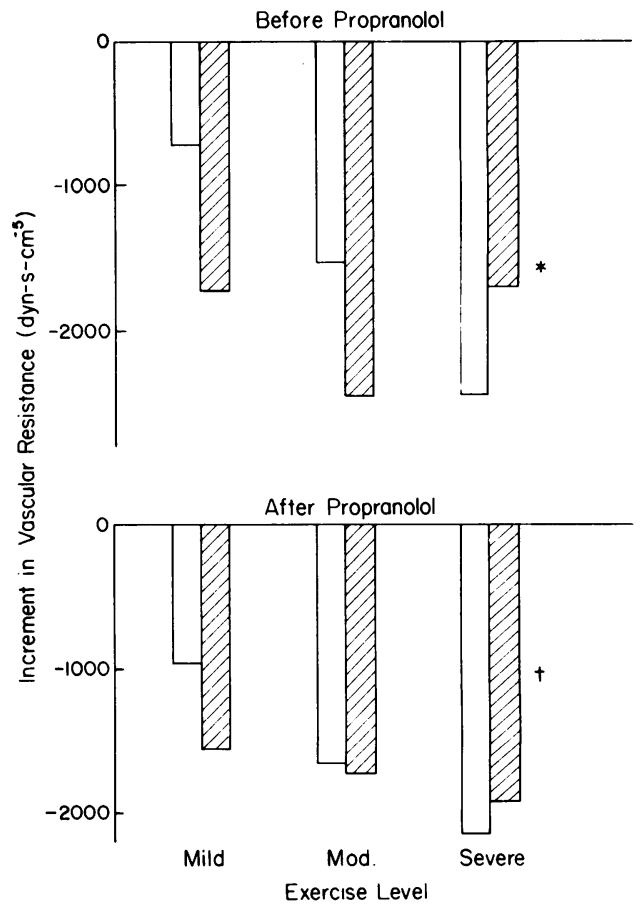

Figure 2 Effect of graded exercise on systemic vascular resistance. Notation is the same as for Fig. 1. Only the decrease across exercise levels in the young group before propranolol was significant $(P=0.002)$. The different response in the old and young groups before propranolol reached statistical significance $(P=0.05) . \square$, young; $\mathbb{m}$, old. ${ }^{*} P=0.05 ; \nmid P$ $=$ NS. Drug $\times$ Age, $P=$ NS. 


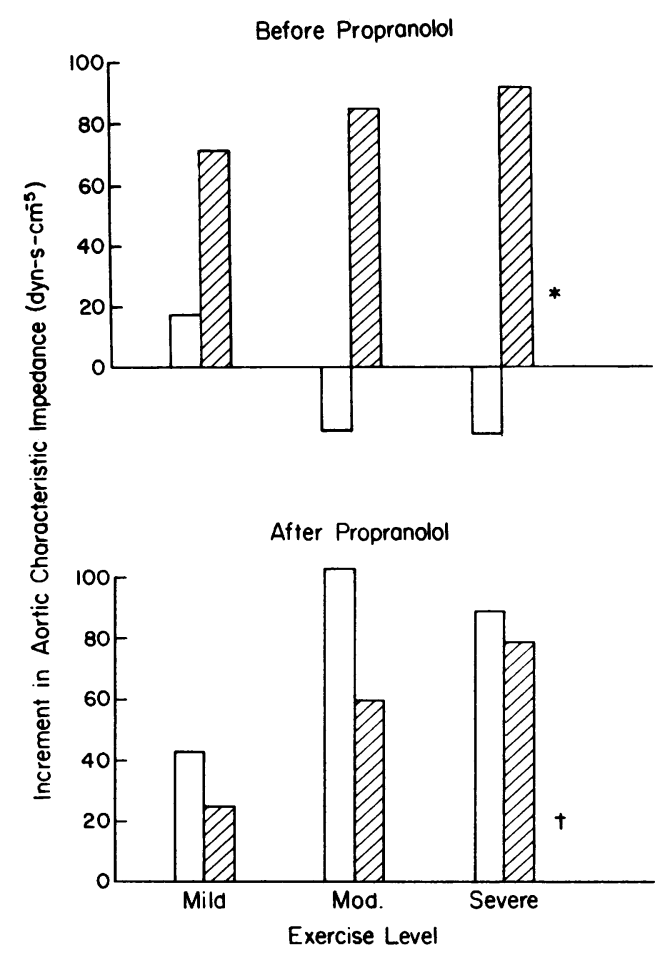

Figure 3 Effect of graded exercise on aortic characteristic impedance. Notation is the same as for Fig. 1. There is no effect across different exercise levels before propranolol, but the age differences in response were highly significant. After propranolol there was a progressive increase in this pulsatile load component at successive exercise levels $(P=0.03)$, but there was no age difference in this response. $\square$, young; $\mathbb{Z}$, old. ${ }^{*} P=0.006 ; \nmid P=$ NS. Drug $\times$ Age, $P=$ NS.

reduce stroke volume or ventricular function $(13,27)$. Most investigations of the effects of "afterload reducing agents" on left ventricular function have focused only on the resistive component of load and have demonstrated a reciprocal relationship between resistance and ventricular function $(31,32)$. These studies concluded that a reduction in resistance was the major cause of improved left ventricular function, but it would not be surprising to find that the pulsatile load component played a similar role. A recent study in humans (33) was the first to measure the pulsatile load component during vasodilator therapy, but the independent effects of the pulsatile and steady load components could not be clearly assessed.

In situations in which the load components are altered in opposite directions, it is difficult to predict a priori which component would dominate in its effects on ventricular function. Two studies using mechanical analogues of the vasculature $(13,34)$ demonstrated that capacitance changes had qualitatively larger effects on stroke volume than resistance changes. Decreases of 21 and $50 \%$ in capacitance produced $\sim 20 \%$ decrease in stroke volume, whereas 208 and $78 \%$ in-

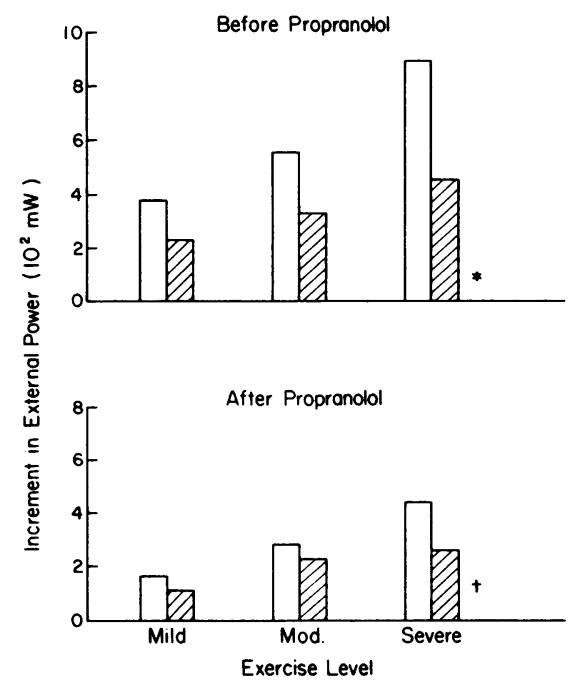

FIGURE 4 Effect of graded exercise on total left ventricular external power. Notation is the same as for Fig. 1. Before propranolol the progressive increase is significant for both the young $(P<0.001)$, and old $(P=0.003)$ groups and the age difference in the response is highly significant. After propranolol there is still a progressive increase with exercise in both the young $(P<0.001)$ and old $(P<0.001)$ groups, but the age difference is not significant. $\square$, young; $\mathbb{m}$, old $* P=0.008$; $\nmid P=$ NS. Drug $\times$ Age, $P=0.04$.

creases in resistance produced only $\sim 30 \%$ decrease in stroke volume. In another study in which the descending aorta was artificially stiffened by application of lucite ferrules (27; dog 29), there was an estimated $40 \%$ increase in characteristic impedance, no change in resistance, and a 29\% decrease in stroke volume. Additionally, a recent study (35) in which reșistance and venous return were held constant during aortic clamping in open-chest dogs demonstrated that compared with control conditions, there was a $46 \%$ decrease in left ventricular circumferential shortening velocity associated with a $36 \%$ increase in aortic characteristic impedance. An experimental intervention which would alter the resistance and impedance components in opposite directions in vivo is not easy to conceive. As shown in this study as well as in two previous studies, $(23,24)$, exercise produced directionally opposite changes in the load components in selected cases. The present results demonstrated that beginning at low levels of exercise in the old group a limitation of stroke volume occurred in conjunction with a $20 \%$ increase in characteristic impedance despite a $28 \%$ decrease in resistance. Thus, in basic agreement with the findings of the mechanical analogue and dog studies mentioned above, this study supports the concept that small changes in the pulsatile component of load can have significant effects on ventricular function independent of changes in resistance.

Because there are other determinants of stroke volume during exercise which we did not measure di- 
rectly, including cardiac compensation by use of inotropic mechanisms and use of the Starling mechanism, we cannot exclude the possibility that ageassociated diminution in these responses also contributed to the limitation in stroke volume. In terms of use of the Starling mechanism, we have demonstrated that the senescent human heart was able to use cardiac dilatation as a compensatory mechanism but did so only when severe hemodynamic stress was imposed (36). More recently, in a study of the exercise response in old and young men, echocardiography was used to measure ventricular dimensions. We found that ventricular dilatation was used at a lower level of exercise by the old men than by young men in response to the stress of exercise (37). Thus, we feel that it is unlikely that the limitation in stroke volume in these old dogs was due to an inability to compensate by use of the Starling mechanism, particularly at the lower exercise levels. However, since we did not directly measure an index of left ventricular diastolic size in these dogs, we cannot state with certainty that an age-associated differential response in diastolic ventricular volumes was not a causative factor in the exercise response.

In addition, whether the limitation in the stroke volume at all levels of exercise in senescent dogs is, in part, due to an intrinsic deficit of inotropic capability is difficult to determine from the present results. One clue may lie in the observations of aortic acceleration of blood (before beta blockade, Table III), which is influenced by both inotropy and load (38). At the lowest level of exercise there was no significant age difference in acceleration, in spite of the difference in load, which argues that the load, rather than decreased inotropy, was responsible for the diminished stroke volume response under these circumstances. The data on the hydraulic power, which is also affected by both inotropy and load (28), raise the possibility that load is not the only factor involved. The fact that the age difference in power response (Fig. 4) becomes progressively greater as the level of exercise is increased, whereas the age difference in load (Fig. 3) does not, suggests that inotropy may be a factor at the higher levels of exertion. This, however, is only indirect evidence. The possibility of an inotropic deficit is supported by the observation that isolated heart muscle from senescent animals has a diminished inotropic response to both catecholamines and cardiac glycosides $(8,39)$. A recent study demonstrated a markedly attenuated ejection fraction response during exercise in old compared with young individuals (5) and ascribed this finding to an inotropic deficit, although the authors recognized that age changes in loading or use of the Starling mechanism could also have been factors.

The diminished stroke volume response in the old dogs could be due in part to alteration in the other organ systems, including a diminished respiratory response, increased thoracic cage stiffness, metabolic and hormonal differences, and skeletal muscle deficits. We did not examine these factors in our study so we cannot exclude them as factors contributing to our findings. In addition, less easily measured effects, such as an age-associated differential response to thoracotomy or psychological response to exercise, could also have contributed. However, the fact that many studies over the years in isolated tissue $(8,17,18,20,39)$ have demonstrated age-associated alterations in response to various interventions, including other forms of stress, suggests that alterations in the cardiovascular system play a major role in the differential exercise response with age. Because of this background information our findings were predictable. The exact role played by the factors mentioned above certainly needs delineation.

The alteration in pulsatile load in the old dogs was not accompanied by statistically significant alterations in the percentage of pulsatile power, reflecting an unchanged efficiency of energy transfer from the heart to the vasculature (27). In both age groups, the percentage of pulsatile power did not change with exercise, although the absolute values of the pulsatile power increased. The magnitude of the oscillatory component of power $\left(\mathrm{W}_{0}\right)$ increased with exercise in both old and young dogs. At the severe level of exercise, for example, it rose in the young animals from $104 \pm 48 \mathrm{~mW}$ at rest to $343 \pm 139 \mathrm{~mW}$ while running. The comparable values for old dogs were $95 \pm 8 \mathrm{~mW}$ and $246 \pm 70 \mathrm{~mW}$, respectively. In both groups, but particularly in the young, the increased oscillatory power was largely attributable to the increase of stroke volume which is an important factor because $W_{0}$ is proportional to the square of the flow harmonics (26). One might have expected the older animals to have a greater increment of oscillatory power with exercise because of their increase in aortic characteristic impedance (which is also one determinant of $W_{0}$ ), but this effect was apparently outweighed by the larger rise in stroke volume in the young dogs compared with the relatively small increase in old ones.

The mechanism(s) for the age differences in response of the characteristic impedance during exercise are not elucidated by the results of this study, but we can identify certain likely possibilities. Characteristic impedance depends on a complex interplay between the size and material properties of the more proximal vasculature such that an increased diameter of the aorta decreases and an increased stiffness raises the input impedance $(15,16)$. Previous studies indicated that stiffness of senescent arterial vessels tended to be higher than in young vessels of the same species $(17$, 18). Other studies have demonstrated a larger size of comparable arterial vessels in old compared with young animals (19). Thus, the old vasculature is likely to be operating on a stress-strain curve that is shifted toward 
higher stiffness for a given stress level as well as on a steeper portion of its nonlinear stress-strain curve. The lack of age difference in characteristic impedance at rest may represent a counterbalancing of the opposing effects of greater diameter and increased stiffness.

The response of the aorta in terms of diameter and stiffness during exercise was not measured directly in the present study. The increased distending pressure would tend to increase aortic diameter. Alpha adrenergic stimulation produced by catecholamine release would cause a leftward and upward shift of the stressstrain curve, resulting in greater stiffness at a given diameter (38). Beta adrenergic stimulation would have the opposite effects. The net result of these changes on impedance would depend on the relative innervation of the aorta, its activation and adrenergic receptormediated smooth muscle responses. Apparently during exercise the old vascular system was operating at a point on a stress-strain curve that resulted in an increase in impedance. On the other hand, the young system continued to operate at a point whereby the size and stiffness changes continued to counterbalance resulting in no net change in impedance.

Some insight into the mechanism(s) responsible for the age-associated difference in vascular response to exercise can be obtained by examination of the effects of beta blockade. The finding that during exercise beta blockade abolished the age difference but not the responses themselves strongly suggested that the age difference in vascular response was, in part, adrenergically mediated via beta receptors. With particular reference to the characteristic impedance $\left(Z_{0}\right)$, the response of the young group before beta blockade (no increment in $\mathrm{Z}_{0}$ ) was converted into a response similar to the old (a constant increment in $\mathrm{Z}_{0}$ across exercise levels) after beta blockade. Concomitantly, there was a marked blunting of the stroke volume response. One explanation for this finding is that the younger aorta may have more ability to vasodilate than the older aorta when subjected to equivalent levels of catecholamines released during exercise. This vasodilatory response is blunted during beta blockade, resulting in the young animal operating at a point such that its $\mathrm{Z}_{0}$ was now increased during exercise. In vitro studies have demonstrated a greater vasodilatory response in young compared with old aorta during equivalent levels of pharmacologic beta adrenergic stimulation, whereas there was no age difference in vasodilatation during nonadrenergic stimulation (20). Another possible explanation is that the young vasculature is more responsive to the vasoconstricting effects of alpha agonists whose effects thus become more apparent in the young after beta blockade. At this higher level of smooth muscle tone unmasked by beta blockade, the young vasculature would then be operating at a point on its stress-strain curve that was shifted nearer that of the intrinsically stiffer old vasculature, thereby obliterating the age difference. To our knowledge, however, there are no reports of an age-dependent differential response to alpha adrenergically induced vasoconstriction.

A less likely explanation for some of the above findings is that the degree of beta blockade attained was greater in the young than the old. However, the findings that in both age groups the degree of beta blockade, as assessed by the isoproterenol challenge and the decrement in inotropy, as assessed by the decrement in maximum aortic acceleration (Table IV), produced by this dose of propranolol was similar, leads us to doubt that there was a significant age difference in beta blockade that was specifically localized to the vasculature.

In summary, this study demonstrated that $(a)$ there were no differences between young and senescent dogs in resting hemodynamic or derived aortic impedance parameters. (b) During exercise there was a profound difference in response of the young and senescent vasculature. The senescent vascular system responded to graded exercise with a constant increment in characteristic impedance and hence an increase in pulsatile load, whereas the young vascular system did not. (c) Accompanying the constant level of vascular loading across exercise levels in the old dogs was a limitation in stroke volume. This resulted in a markedly diminished cardiac output response to progressive exercise compared with the young dogs in whom the stroke volume was not limited by vascular loading of the heart. $(d)$ This age difference in vascular response was abolished after beta adrenergic blockade. (e) At low and intermediate exercise levels, vascular loading appeared to be one of the major factors in limitation of stroke volume in the senescent animal. At high levels of exercise, the limited exercise response in the senescent dog may be caused, in part, by a diminished inotropic responsiveness, as well as by the vascular loading.

\section{ACKNOWLEDGMENTS}

We thank Mr. Fred Jackson whose invaluable technical assistance made this study possible. We also thank Ms. Joyce Ziskind for secretarial assistance in completing the manuscript.

This work was supported in part by a grant-in-aid from the American Heart Association-Maryland Affiliate to Dr. Yin from July 1978 to June 1979 , and by grant HL-12607 from the U. S. Public Health Service.

\section{REFERENCES}

1. Master, A. M., and E. T. Oppenheimer. 1929. A simple exercise tolerance test for circulatory efficiency with standard tables for normal individuals. Am. J. Med. Sci. 77: 221-243. 
2. Robinson, S. 1978. Experimental studies of physical fitness in relation to age. Arb. Physiol. 10: 251-323.

3. Strandell, T. 1964. Heart rate, arterial lactate concentration, and oxygen uptake during exercise in old men compared with young men. Acta Physiol. Scand. 60: $197-216$.

4. Granath, A., B. Jonsson, and T. Strandell. 1964. Circulation in healthy old men studied by right heart catheterization at rest and during exercise in supine and sitting position. Acta Med. Scand. 176: 425-446.

5. Port, S., F. R. Cobb, R. E. Coleman, and R. H. Jones. 1980. The effect of age on the response of the left ventricular ejection fraction to exercise. N. Engl. J. Med. 303: 11331137.

6. Martin, C. E., J. A. Shaver, D. F. Leon, M. E. Thompson, P. S. Reddy, and J. J. Leonard. 1974. Autonomic mechanisms in hemodynamic responses to isometric exercise. J. Clin. Invest. 54: 104-115.

7. Conway, J., R. Wheeler, and R. Sannerstedt. 1971. Sympathetic nervous activity during exercise in relation to age. Cardiovasc. Res. 5: 577-581.

8. Lakatta, E. G., G. Gerstenblith, C. S. Angell, N. W. Shock, and M. L. Weisfeldt. 1975. Diminished inotropic response of aged myocardium to catecholamines. Circ. Res. 36: 262-269.

9. Yin, F. C. P., H. A. Spurgeon, H. L. Greene, E. G. Lakatta, and M. L. Weisfeldt. 1979. Age-associated decrease in heart rate response to isoproterenol in dogs. Mech. Ageing Dev. 10: 17-25.

10. Wilcken, D. E. L., A. A. Charlier, J. I. E. Hoffman, and A. Guz. 1964. Effects of alterations in aortic impedance on the performance of the ventricles. Circ. Res. 14: 283-293.

11. Urschel, C. W., J. W. Covell, E. H. Sonnenblick, J. Ross, Jr., and E. Braunwald. 1968. Effects of decreased aortic compliance on performance of the left ventricle. Am.J. Physiol. 214: 298-304.

12. Milnor, W. R. 1975. Arterial impedance as ventricular afterload. Circ. Res. 36: 565-570.

13. Elzinga, G., and N. Westerhof. 1973. Pressure and flow generated by the left ventricle against difference impedances. Circ. Res. 32: 178-186.

14. Patel, D. J., F. M. De Freitas, and D. L. Fry. 1963. Hydraulic input impedance to aorta and pulmonary artery in dogs. J. Appl. Physiol. 18: 134-140.

15. Womersley, J. R. 1957. The mathematical analysis of the arterial circulation in a state of oscillatory motion. Wright Air Development Center, Technical Report WADC-TR 56-614.

16. MacDonald, D. A. 1974. Blood flow in arteries. The Williams \& Wilkins Company, Baltimore, Md. 351-388.

17. Learoyd, B. M., and M. G. Taylor. 1966. Alterations with age in the viscoelastic properties of human arterial walls. Circ. Res. 18: 278-292.

18. Band, W., W. J. A. Goedhard, and A. A. Knoop. 1972. Effects of aging on dynamic viscoelastic properties of the rats' thoracic aorta. Pfluegers. Arch. 331: 357-364.

19. Bader, H., and E. Kapal. 1957. Relationship between radius and wall thickness of human thoracic aorta at different ages and different pressures. Physiologist. 2: 4.

20. Fleisch, J. H., and C. S. Hooker. 1976. The relationship between age and relaxation of vascular smooth muscle in the rabbit and rat. Circ. Res. 38: 243-249.

21. Nichols, W. W., C. R. Conti, W. E. Walker, and W. R. Milnor. 1977. Input impedance of the systemic circulation in man. Circ. Res. 40: 451-458.

22. Merillon, J. P., G. Matte, J. Fruchaud, C. Masquet, and R. Gourgon, 1978. Evaluation of the elasticity and character- istic impedance of the ascending aorta in man. Cardiovasc. Res. 12: 401-406.

23. Pepine, C. J., W. W. Nichols, L. G. Christie, and C. R. Conti. 1977. Divergence of left ventricular afterload components during exercise in man. Physiologist. 20: 73.

24. Nichols, W. W., C. J. Pepine, R. L. Feldman, L. G. Christie, and C. R. Conti. 1980. Exercise induced changes in aortic input impedance in mild hypertension. Circulation. 62: III-258.

25. Walker, W. E. 1975. The influence of changes of aortic input impedance on the dynamics of left ventricular performance. Ph.D. Thesis, Department of Physiology, Johns Hopkins University, Baltimore, Md.

26. Milnor, W. R., D. H. Bergel, and J. D. Bargainer. 1966. Hydraulic power associated with pulmonary blood flow and its relation to heart rate. Circ. Res. 19: 467-480.

27. O'Rourke, M. F. 1967. Steady and pulsatile energy losses in the systemic circulation under normal conditions and in simulated arterial disease. Cardiovasc. Res. 1: 313-326.

28. Cox, R. H. 1974. Determinants of systemic hydraulic power in unanesthetized dogs. Am. J. Physiol. 226: 579-587.

29. Snedecor, G. W., and W. G. Cochran. 1867. In Statistical Methods. 6th edition. Iowa State University Press, Ames, Iowa 91-116.

30. Winer, B. J. 1971. Statistical Principles in Experimental Design. 2nd edition. McGraw-Hill Book Company, New York. 514-603.

31. Miller, R. R., L. A. Vismara, D. O. Williams, E. A. Amsterdam, and D. T. Mason. 1976. Pharmacologic mechanisms for left ventricular unloading in clinical congestive heart failure. Circ. Res. 39: 127-133.

32. Cohn, J. N., K. J. Mathew, J. A. Franciosa, and J. A. Snow. 1979. Chronic vasodilator therapy in the management of cardiogenic shock and intractable left ventricular failure. Ann. Intern. Med. 81: 777-780.

33. Pepine, C. J., W. W. Nichols, R. C. Curry, Jr., and C.R. Conti. 1979. Aortic input impedance during nitroprusside infusion. J. Clin. Invest. 64: 643-654.

34. Ishide, N., Y. Shimuzu, T. Maruyama, Y. Koiwa, T. Nunokawa, S. Isoyama, S. Kitaoka, K. Tamaki, E. Inooka, and T. Takishima. 1980. Effects of changes in the aortic input impedance on systolic pressure-ejected volume relationships in the isolated supported canine left ventricle. Cardiovasc. Res. 14: 229-243.

35. Pouleur, H., J. W. Covell, and J. Ross, Jr. 1979. Effects of alterations in aortic input impedance on the forcevelocity-length relationship in the intact canine heart. Circ. Res. 45: 126-135.

36. Yin, F. C. P., G. S. Raizes, T. Guarnieri, H. A. Spurgeon, E. G. Lakatta, N. J. Fortuin, and M. L. Weisfeldt. 1978. Age-associated decrease in ventricular response to haemodynamic stress during beta-adrenergic blockade. $\mathrm{Br}$. Heart J. 40: 1349-1355.

37. VanTosh, A., E: G. Lakatta, J. L. Fleg, J. Weiss, C. Kallman, M. Weisfeldt, and G. Gerstenblith. 1980. Ventricular dimension changes during submaximal exercise: effect of aging in normal man. Circulation. 62: III-483.

38. Rushmer, R. F. 1964. Origins of pulsatile flow: the ventricular impulse generator. In Pulsatile Blood Flow. E. O. Attinger, editor. McGraw-Hill Book Company, New York. 11: 221-236.

39. Gerstenblith, G., H. A. Spurgeon, J. P. Froehlich, M. L. Weisfeldt, and E. G. Lakatta. 1979. Diminished inotropic responsiveness to ouabain in aged rat myocardium. Circ. Res. 44: 517-523.

40. Dobrin, P. B. 1978. Mechanical properties of arteries. Physiol. Rev. 58: 397-460. 